\title{
Thomas Lewis, a father of modern cardiology
}

\author{
Dennis M Krikler (Editor Emeritus, British Heart fournal/Heart)
}

Those interested in the history of cardiology, especially its transatlantic links, had a double dose of information and pleasure in 1996. Bruce Fye's definitive history of modern American cardiology ${ }^{1}$ was published and Arthur Hollman completed a biography of Sir Thomas Lewis2: both books do much to sustain each other.

Sir Thomas Lewis was a founding member and the first chairman of the Cardiac Club in 1922 , and when the club became fully fledged as a society in 1937 he became the first president of the British Cardiac Society. Despite his prominence in cardiology he considered his career to be based in clinical science: much of the work he did during the last 20 years of his life was done on the perception of pain, peripheral vascular disease and its manifestations, and cutaneous responses to injury. As his early publications show, Lewis was the right man at the right time. In 1908 he met Sir James Mackenzie, when Mackenzie moved from Burnley to London. Mackenzie, a general practitioner, was respected throughout Europe for his cardiological observations, which he based on clinical judgement and his polygraph. Hollman tells us how Mackenzie's influence led Lewis to use the electrocardiograph to clarify disorders of cardiac rhythm. In his early and very productive years in cardiology Lewis also came to know the inventor of the modern electrocardiograph, Willem Einthoven. Hollman describes the meetings between Einthoven and Lewis as well as their correspondence, which was edited by Snellen. ${ }^{3}$

Lewis pointed out to Mackenzie the need for a journal in which disorders of the cardiovascular system could be discussed, and Mackenzie established Heart with Lewis as its editor. Later, as Lewis's interests changed, the journal became Clinical Science. By today's standards Lewis was a highly idiosyncratic editor, who published issues whenever sufficient material that he judged to be appropriate was ready. Much of the work submitted came from his own laboratory and colleagues. The eminence of a prospective author did not save him from scorn if Lewis did not agree with what he received.

Lewis's scientific precocity won him early advancement. Though he later turned to other fields of research, he continued to take an interest in cardiology and to produce further editions of textbooks. Indeed the last editions of Diseases of the Heart (1946) and Electrocardiography and Clinical Disorders of the Heart Beat (1949) both appeared posthumously. But his most eloquent memorial must surely be the third edition of his Mechanism and Graphic Registration of the Heart Beat, published in 1925. Quite apart from its content, its presentation was exceptional, with the bibliographical index set out in a remarkably helpful way. The one group of arrhythmias that evaded Lewis's grasp was the pre-excitation syndrome, the first series of cases of which was reported by the Anglo-American team of Wolff, Parkinson, and White ${ }^{4}$; the British author, John Parkinson, had also been greatly influenced by James Mackenzie.

We cannot give a definite answer to the question so often posed now: did electrocardiography define modern cardiology? As Fye points out, during the first two decades of this century several different categories of physicians and laboratory-based scientists became interested in cardiology, ranging from clinical physiologists to clinicians and teachers. By any definition James Mackenzie was a cardiologist, both in terms of his practice interests and the knowledge that he acquired both clinically and using the polygraph. The electrocardiograph became the first tool to define the special interest and expertise of the cardiologist. ${ }^{5}$

Lewis carved out a special role for what he called clinical science in the practice of medicine and research and teaching. Soon after the Medical Research Committee was established he became its first scientist-employee; the organisation evolved into the Medical Research Council. Lewis remained associated with the MRC throughout his working life, though after 1932 he was no longer funded by it: his post became endowed by the Rockefeller Foundation.

When the Nazis came to power in Germany in 1933 Lewis urged and helped his former research fellow Paul Rothschild to return to England, and he campaigned to find homes and work in Britain for other refugee scientists. Curiously, Lewis's humane response had a lot to do with the establishment of the American College of Cardiology. Fye's book describes this aspect particularly vividly.

The American Heart Association had been formed in 1924, but just after the Second 
World War (1946-48) converted itself from being an organisation of cardiologists into a more general organisation that also involved lay people in public education and health promotion. In addition many more refugees had been able to enter the United States than Britain but they found themselves looked upon with suspicion by the leading figures in the American Heart Association. Thus in the mid 40s some American cardiologists believed that they needed a new professional organisation to serve their intellectual and scientific needs.

The origins of the American College of Cardiology lie in the New York Cardiological Society. ${ }^{6}$ By 1926 cardiologists from the Eastern seaboard, mainly in New England, felt the need for a professional body which could hold scientific meetings and on 26 October 1926 one was constituted as the Sir James Mackenzie Cardiological Society, under the presidency of Albert Hyman, who was "the last American medical student to have worked under his direction" and who had been in London when Mackenzie died in January 1925. By September 1928 the Society had held "eleven regular meetings, five clinical meetings and three meetings in collaboration with other medical societies". There were, however, problems with the name, which had little resonance among the younger members, so the organisation became the New York Cardiological Society-and 21 years later the American College of Cardiology.

Two leading refugee cardiologists, Franz Groedel and Bruno Kisch, worked together with Louis F Bishop and others in the New York Cardiological Society to establish what in 1949 became the American College of Cardiology. Fye goes further back and picks up the roots of the development of cardiology in the United States: both books emphasise the strong influence of Lewis's school at University College Hospital, London, which until the mid-20s was a magnet for American postgraduates, who previously had found more encouragement on the Continent. Starting with Alfred E Cohn, they came to Lewis and took back to the United States an understanding of electrocardiography. Among these American disciples were Frank N Wilson and Paul Dudley White. White became renowned for his classic textbook on cardiology and his major roles at the Massachusetts General Hospital and in international cardiological organisations.

Hollman sets the scene for the development of the concepts of Lewis and Mackenzie that led to cardiac surgery, starting with the correction of valve lesions. Fye too covers this amply. Hollman stresses the British contribution to developments in the diagnosis of coronary artery disease such as cardiac catheterisation and electrocardiography. In describing Lewis and his work, Hollman brings to life a host of other characters and contributors and tells us a much wider story of British cardiology and medicine than one might think would flow from the subject of his biography. Fye, an equally talented and perceptive author, does full justice to the intellectual and technical advances that we owe to American cardiology. Interestingly, the writing of both books was much helped by taperecorded conversations with those who recollected being at the frontiers of these advances. Each book gives us reason to pause and take stock of how cardiology has developed over the past century and to remind ourselves of our distinguished predecessors in the specialty. And, for those who want to know more, each book provides a comprehensive bibliography and a meticulous index. 1996 was indeed a bumper year for those with an interest in the key personalities who enabled 20th century cardiology to flourish.

1 Fye WB. American cardiology. The history of a specialty and its college. Baltimore and London: Johns Hopkins University Press, 1996.

2 Hollman A. Sir Thomas Lewis. Pioneer cardiologist and clinical scientist. London: Springer-Verlag, 1997.

3 Snellen HA. Two pioneers of electrocardiography. The corre spondence between Einthoven and Lewis from 1908-1926. spondence between Einthoven and Lewis from 1908-19

4 Wolff L, Parkinson J, White PD. Bundle-branch block with short PR interval in healthy young people prone to paroxshort PR interval in healthy young people prone

5 Krikler DM. Electrocardiography then and now: where next? $\mathrm{Br} \mathrm{Heart} \mathcal{f} 1987 ; 57: 113-7$.

6 Kligfield P, Hollman A. The Sir James Mackenzie Cardiological Society and the American College of Cardiology. Am F Cardiol 1996;78:808-13. 